\title{
Spatial distribution of garnet indicating control of bulk rock chemistry in the Sanbagawa metamorphic rocks, Kanto Mountains, Japan
}

\author{
Mutsuko INUI ${ }^{*}$ and Ayato TANIFUJI ${ }^{* * *}$ \\ *School of Science and Engineering, Kokushikan University, Tokyo 154-8515, Japan \\ ${ }^{* *}$ Present Affiliation: Family Mart Co., Ltd.
}

\begin{abstract}
Traditional metamorphic geology admitted that the appearance of specific index mineral, such as garnet, indicated the rocks experienced higher peak metamorphic condition. It is largely true, but it is still unclear what is going on in the rocks at the very start of the garnet formation. One of the key must lie in the area where apparent isograd is outcropped. Nagatoro area is located in the Kanto Mountains, and it is where the low grade metamorphic rocks of the Sanbagawa metamorphic belt are exposed. Appearance of garnet is the index of the higher metamorphic grade in this area. Several outcrops in Nagatoro area are known to contain garnet, thus being good samples of the outcropped isograd. In this study, spatial distribution of garnet within such an outcrop several tens of meters long was investigated. The samples are pelitic schists, and the mineral assemblage was basically quartz, plagioclase, muscovite, and chlorite. 36 of the 55 samples contained garnet. Garnet grains were small, most of them with diameters less than $100 \mu \mathrm{m}$. Most of the garnet grains were euhedral to subhedral and were found within micaceous lamellae which form the foliations of the pelitic metamorphic rocks. The micaceous lamellae were constituted mainly by muscovite with lesser amount of chlorite. Occurrence of garnet-bearing rocks within the outcrop seemed to be restricted in certain structural layers. The structural layers are known to be nearly parallel to the lithologic boundary in this area. Mapped chemical profiles of garnet revealed that the garnet grains exhibited euhedral growth of the crystal. The core part was relatively large and homogeneous, with quite a high $\mathrm{Mn}$ end-member (spessartine) content $\left(X_{\mathrm{Sps}}>50 \%\right)$. Irregular shaped inner core was preserved. These features indicate that the texture preserves the beginning stage of garnet growth. The trend of chemical composition of garnet rim and adjacent chlorite is consistent with the bulk rock chemistry control. Spatial distribution of garnet, at the start of its growth, was probably controlled by the bulk rock chemistry.
\end{abstract}

Keywords: Garnet, Bulk rock chemistry, Spatial distribution, Sanbagawa metamorphic belt

\section{INTRODUCTION}

Garnet is one of the most popular metamorphic index minerals that are utilized to determine the isograd. Traditional metamorphic geology has interpreted that the presence of garnet, or other index mineral, represents that the rocks experienced specific peak metamorphic condition. Decades ago, progress in metamorphic petrology has revealed to us that just the existence or non-existence of some index mineral is not enough to tell something, but the growth process of the index mineral is important. Spear and Selverstone (1983) proposed the way to discuss

doi:10.2465/jmps.170712b

M. Inui, inui@kokushikan.ac.jp Corresponding author the metamorphic pressure and temperature quantitatively using the mineral zonation. Sakai et al. (1985) investigated the garnet growth history in the Sanbagawa metamorphic belt using garnet zoning. Recently, the dynamics of the crystal formation is being discussed in detail, since the garnet formation is always a continuous reaction and is influenced by many other factors as well as by static pressure and temperature. The thermal overstepping is thought to be required and its magnitude and influence has been explored (Spear et al., 2014). Interfacial energy of minerals has been considered in forward simulations of garnet forming (Gaidies et al., 2011). Still, it is not clear enough what is going on in the rocks at the very start of the garnet formation. One of the key must lie in the area where apparent 'isograd' is outcropped. In this study, spatial distri- 
bution of garnet within an outcrop several tens of meters long was determined. Some implications were obtained on how garnet starts to form in a regional metamorphism, through the spatial distribution and chemical analyses of the minerals in the Sanbagawa metamorphic rocks.

\section{GEOLOGIC SETTING}

The Sanbagawa metamorphic belt in the southwestern part of Japan islands is exposed mainly along arc (Fig. 1). It is one of the most investigated subduction zone relics in the world (e.g., Banno and Sakai, 1989). The Sanbagawa belt is a metamorphosed accretionary complex which originally consists mainly of alternated sandand mudstone, accompanied by basalt and chert. The highest metamorphic grade part in the terrain shows the eclogite facies mineral assemblage, and is exposed in central Shikoku (Enami et al., 1994; Aoya, 2001). Recent chronological studies performed in the Kanto Mountains area revealed that the protolith of the Sanbagawa belt accreted in the late Cretaceous, and sufferred metamorphism for a little more than 10 m.y. before exhumation (Tsutsumi et al., 2009).

Metamorphic zonation in the Kanto Mountains area, the eastern most part of the Sanbagawa belt, have been defined based on the mineral assemblage of pelitic schists, and also on the analyses of carbonaceous materials, by Hashimoto et al. (1992) as zone I, zone II, and zone III in the ascending order. Zone I pelitic rocks generally contain quartz, plagioclase, muscovite, and chlorite. Zone I is the lowest metamorphic grade zone and is thought to be equivalent to the Chlorite Zone defined in the Shikoku area of the Sanbagawa metamorphic belt (e.g., Higashino, 1990). Garnet appears in Zone II, and biotite in Zone III. Calcite, titanite, or clinozoisite are contained as accessory minerals. The foliation of the schists generally dips slightly north in the area. The lithology is known to be nearly parallel to the foliation (Sakai, 1980; Hashimoto et al., 1992).

The sampling locality of this study is basically in the Zone I (Fig. 1), with subhorizontal foliation. It is known that garnet sometimes occurs in rocks in and near the studied outcrop (e.g., Hashimoto et al., 1992). It has been argued that the local occurrence of garnet demonstrates the existence of structural boundaries (Tagiri et al., 2003). Inui et al. (2018) estimated metamorphic peak temperatures of the samples from the same outcrop using Raman carbonaceous material geothermometer calibration by Beyssac et al. (2002). The estimated temperature was around 400 to $450{ }^{\circ} \mathrm{C}$ with no recognizable gap between garnet-bearing and garnet-free rocks within the outcrop, indicating no structural boundary. The temperature range

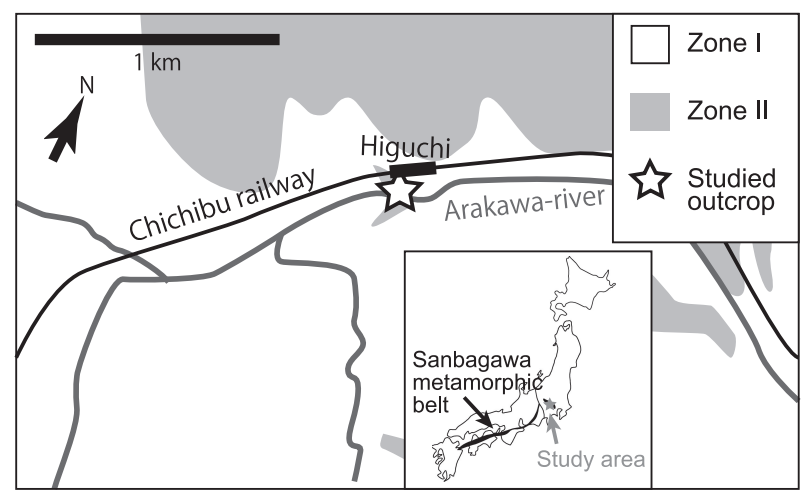

Figure 1. Sampling locality. Modified after Hashimoto et al. (1992). Zone I is the lowest grade zone. Garnet appears in Zone II. Around the outcrop, the area basically is in Zone I, but it is known that garnet occurs in and near the studied outcrop (Hashimoto et al., 1992).

is consistent with the beginning of the garnet formation, since it is comparable to the estimated peak temperature of the equivalent Garnet Zone in central Shikoku which is $440 \pm 15^{\circ} \mathrm{C}$ (Enami, 1998). Occurrence of garnet in the pelitic schists therefore defines the isograd between Zone I and II in the study area.

\section{METHOD}

55 hand samples were taken from the approximately 70 $\mathrm{m}$ wide outcrop to investigate how garnet-bearing and garnet-free rocks are distributed. Investigation was carried out exclusively using pelitic schist samples. The topography of the outcrop was measured and contoured. The spatial distribution of garnet-bearing and garnet-free samples was plotted on the contoured map to show the three-dimensional distribution of garnet. Mineral assemblage and occurrence of garnet within a thin section was observed under polarizing microscope. Chemical mapping analyses of garnet were performed using the electron probe microanalyzer (EPMA) JEOL JXA-8800M at the Graduate School of Arts and Sciences of the University of Tokyo. The acceleration voltage was set to $15 \mathrm{kV}$, beam current was $60 \mathrm{nA}$, beam diameter was focused. Quantitative chemical analyses were performed by the EPMA JEOL JXA-8900 at Nagoya University. The acceleration voltage $15 \mathrm{kV}$, beam current $12 \mathrm{nA}$, and the beam was focused. Correction factors calculated by Kato (2005) were used for the matrix correction. Abbreviations for the names of minerals and end-member components follow Whitney and Evans (2010).

\section{DESCRIPTION}

The studied outcrop consisted mainly of pelitic schists, 

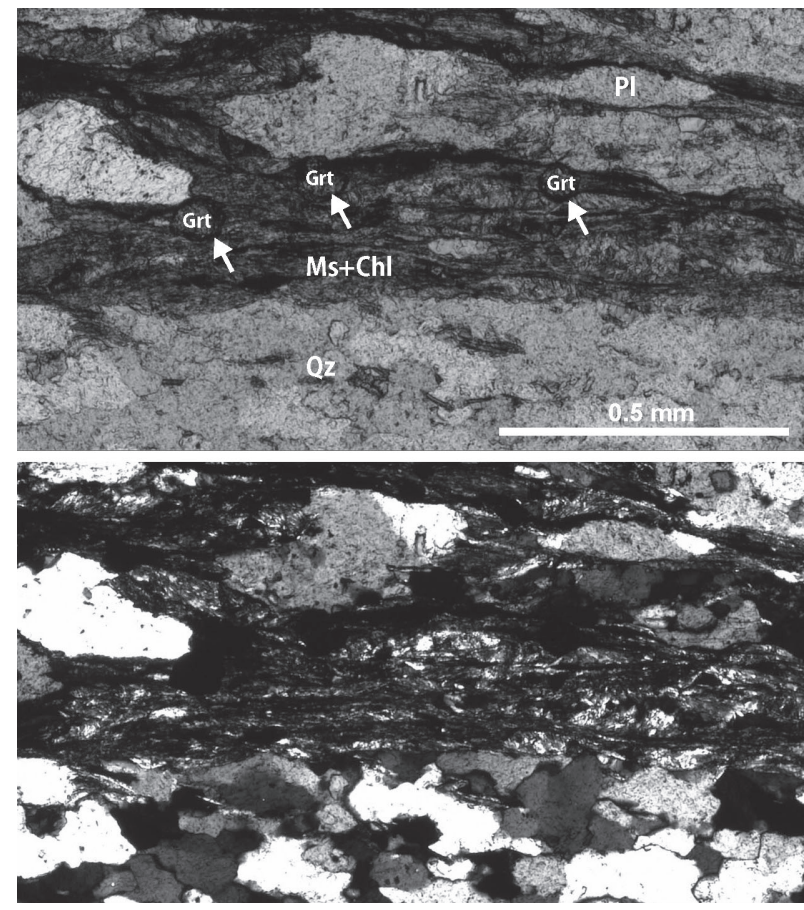

Figure 2. Photomicrograph of garnet-bearing sample 20160902TAD (open and crossed nicols). Garnet grains (Grt, white arrows) are found exclusively in the micaceous lamellae of the thin section which mainly consists of muscovite (Ms) and chlorite (Chl). Plagioclase ( $\mathrm{Pl})$ is mostly found in the micaceous lamellae.

accompanied by minor amount of mafic schists. Some of the pelitic parts showed lighter grey color. (This type of rocks has been described as 'psammitic' in some references, but pelitic and psammitic schists are not distinguished in this study and both types of rocks are referred to as 'pelitic' schists hereafter). Mineral assemblage of the pelitic schists was generally quartz, plagioclase, muscovite, chlorite. Not all the samples contained garnet, calcite, titanite, and epidote. Less than half of the samples contained calcite, most of them on the western part of the outcrop (mapped on Fig. 3a below). Carbonaceous material was also included in many of the samples. The texture under the microscope showed alternating micaceous and siliceous lamellae with the thickness approximately 0.1 to $1.0 \mathrm{~mm}$, which formed the schistosity (Fig. 2). Chlorite and plagioclase were found in the micaceous lamellae. Siliceous lamellae are consisted mostly of quartz.

36 of the 55 samples contained garnet in its mineral assemblage. Mineral assemblage did not show systematic difference between garnet-bearing and garnet-free samples. It is not possible to distinguish the garnet-bearing samples from the garnet-free samples with the naked eye. Garnet grains were small and euhedral to subhedral, most of them with diameters less than $100 \mu \mathrm{m}$ (Fig. 2). Garnet grains always occurred within micaceous lamellae.

\section{RESULTS}

\section{Spatial distribution of garnet}

Spatial distribution of the garnet-bearing and garnet-free rocks were plotted on the contour map of the outcrop (Fig. 3 ). The contoured height data are not the geometric height but was measured perpendicular to the foliation which is subhorizontal (Fig. 3). The height was measured with reference to each ' $0 \mathrm{~m}$ ' point plotted in the same figure. The two ' $0 \mathrm{~m}$ ' points (in Figs. $3 \mathrm{a}$ and $3 \mathrm{~b}$ ) were both located approximately $1.5 \mathrm{~m}$ above the water surface of the river, but it was not possible to confirm whether they were on the same foliation because of vegetation. Therefore, the height data are not strictly comparable between the two area (Figs. 3a and 3b). An apparent structural discontinuity, which was a high-angle fault-like structure, was recognized in the outcrop (Fig 3a). Consequently, the height data on one side of the discontinuity are not comparable to those on the other side. About two thirds of the samples contained garnet. Occurrence of garnet was not at random but was roughly clustered when mapped. Figure 3 a shows that most of the garnet-bearing samples were distributed in the area above $4 \mathrm{~m}$ contour, or in the area below $2 \mathrm{~m}$ contour. Figure $3 \mathrm{~b}$ shows that most of the garnet-bearing samples were found above the $5 \mathrm{~m}$ contour, though it is less clear in the eastern part of the outcrop. Thus, garnet seemed to occur within restricted height ranges, namely structural layers, several meters away from each other. The structural layers (foliation) is known to be nearly parallel to the lithologic boundary in this area. It is interpretable that the garnet concentrated layers are nearly parallel to the lithologic layers. The peak metamorphic temperature estimated using the same samples by Inui et al. (2018) with Raman spectrometry on carbonaceous materials is also shown (Figs. 3a and 3b). There is no detectable difference between the peak temperatures of the garnet-bearing and garnet-free samples.

\section{Chemical trends of garnet and chlorite}

Chemical mapping analyses and quantitative chemical analyses across the garnet grains were performed (Figs. 4 and 5). The representative chemical composition of the core and the rim of the garnet are shown in Table 1 in addition to those of chlorite. Since the garnet grains were generally very small, relatively large grains with the diameter around $100 \mu \mathrm{m}$ were selected for analyses to avoid analytical artifact. The shape of the chemical zoning pattern was euhedral (except the irregular shaped core 

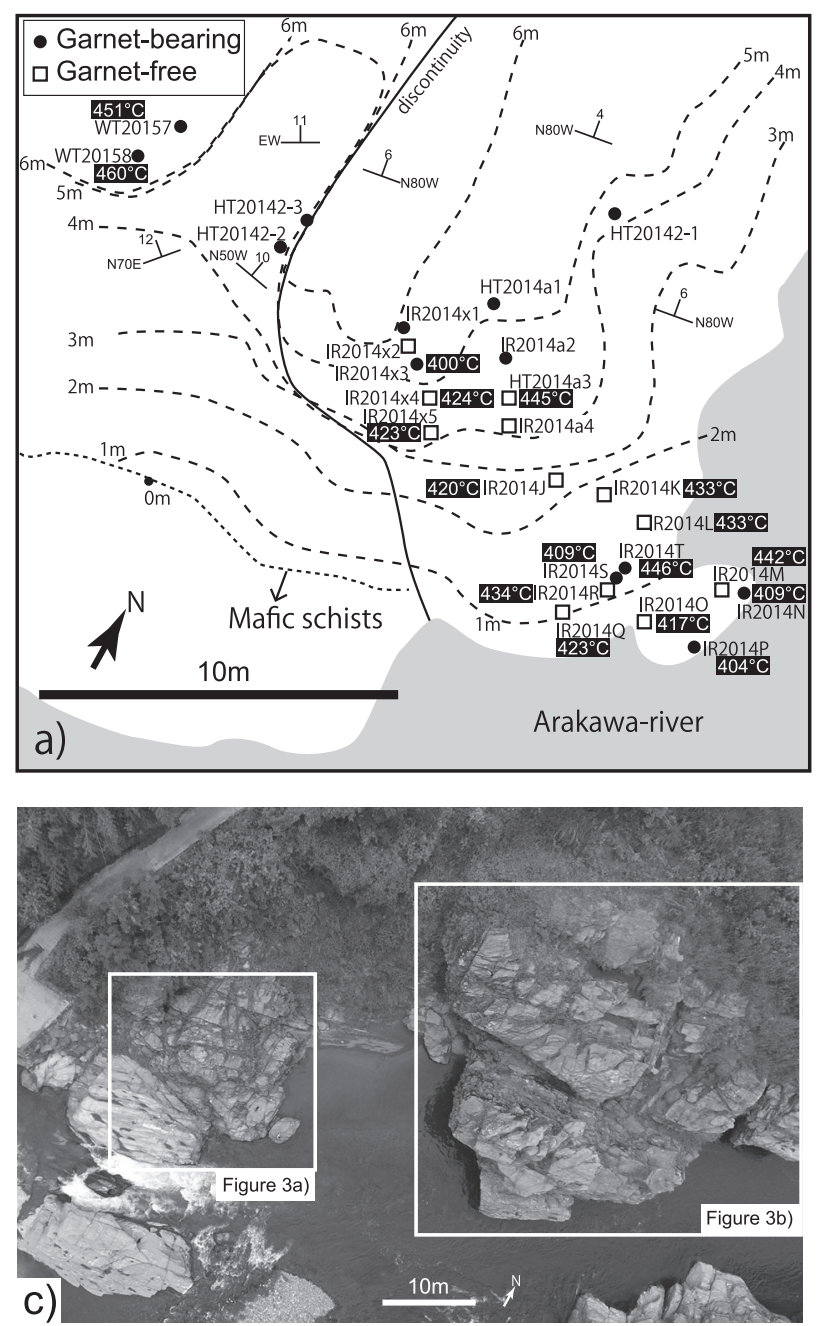

described below) and showed little evidence of disturbance during or after growth. The garnet grains had relatively large homogeneous core, which takes up more than half the radius of the grain itself, and zoned near the rim (Fig. 4). Mn end-member content, $X_{\mathrm{Sps}}$ [mole fraction of spessartine: $\mathrm{Mn} /(\mathrm{Fe}+\mathrm{Mg}+\mathrm{Mn}+\mathrm{Ca})]$, was quite high in the core $\left(X_{\mathrm{Sps}}>50 \%\right)$ (Fig. 5). $X_{\mathrm{Sps}}$ decreased in the rim part as is typical in normal zoning of garnet under prograde condition. $X_{\text {Grs }}$ [mole fraction of grossular: $\mathrm{Ca} /(\mathrm{Fe}+$ $\mathrm{Mg}+\mathrm{Mn}+\mathrm{Ca})]$ showed different zoning profile in sample HT2014al (Fig. 4d) and sample 20160902TAP (Fig. 4h). Sample HT2014al showed relatively flat zoning in grossular, whereas sample 20160902TAP revealed a drastic increase of grossular in the rim compared to the core. Grains contained in the same thin section showed the same zoning profile pattern. At a glance, zoning pattern of $\mathrm{Fe}-\mathrm{Mg}-\mathrm{Mn}$ system looked different between sample HT2014a1 and sample 20160902TAP (Fig. 4), but it seemed to be the effect of drastic Ca composition change between the core and the rim part. $X_{\mathrm{Alm}}[$ mole fraction of

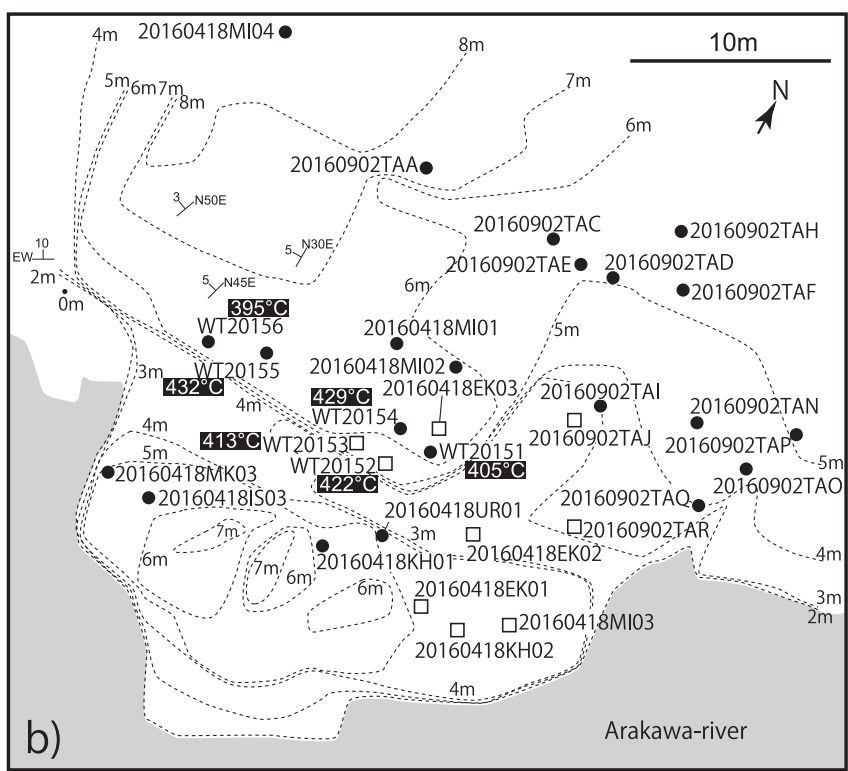

Figure 3. Spatial distribution of garnet-bearing and garnet-free rocks within the studied outcrop. (a) contoured map of the west part of the outcrop. Garnet-bearing samples are mainly found either above $4 \mathrm{~m}$ contour, or below $2 \mathrm{~m}$ contour. (b) contoured map of the east part of the outcrop. Garnet-bearing samples are found above $5 \mathrm{~m}$ contour, although it is not clear in the eastern most part of the map. (c) areas of (a) and (b) shown on an aerialphoto of the outcrop taken by M. Uno. The contoured height is not geometric height but is the length measured perpendicular to the foliation. The measurement was performed with reference to each ' $0 \mathrm{~m}$ ' point shown in (a) and (b). The height data in (a) and (b) are not strictly comparable. The height data on one side of the discontinuity on (a) is not comparable to the data on the other side. The dip data of the foliation are also shown. The peak metamorphic temperature estimated by Inui et al. (2018) based on Raman spectroscopy on the carbonaceous material is shown in white characters on black.

almandine: $\mathrm{Fe} /(\mathrm{Fe}+\mathrm{Mg}+\mathrm{Mn}+\mathrm{Ca})]$ decreased in the rim compared to the core (Fig. 4g), for example, because the total of the $\mathrm{Fe}-\mathrm{Mg}-\mathrm{Mn}$ elements decreased to compensate the large $X_{\text {Grs }}$ increase. Some of the grains exhibited an irregular shaped inner core with low Mn and high Ca content (Fig. $4 \mathrm{e}$ and $4 \mathrm{~h}$ ).

Chemical composition of chlorite differed from sample to sample, seemingly in response to the chemical composition of the adjacent garnet rim (Fig. 6). It was seen that $\mathrm{Mn}$-richer garnet rim was associated with $\mathrm{Mn}$-richer chlorite, which was not explicable by the later exchange reaction between the two minerals.

\section{DISCUSSION AND CONCLUSION}

\section{Controls on the spatial distribution of garnet}

Spatial distribution of garnet suggests that garnet occur within some restricted structural layers (Fig. 3). Traditional explanation would be that the garnet-bearing rocks 

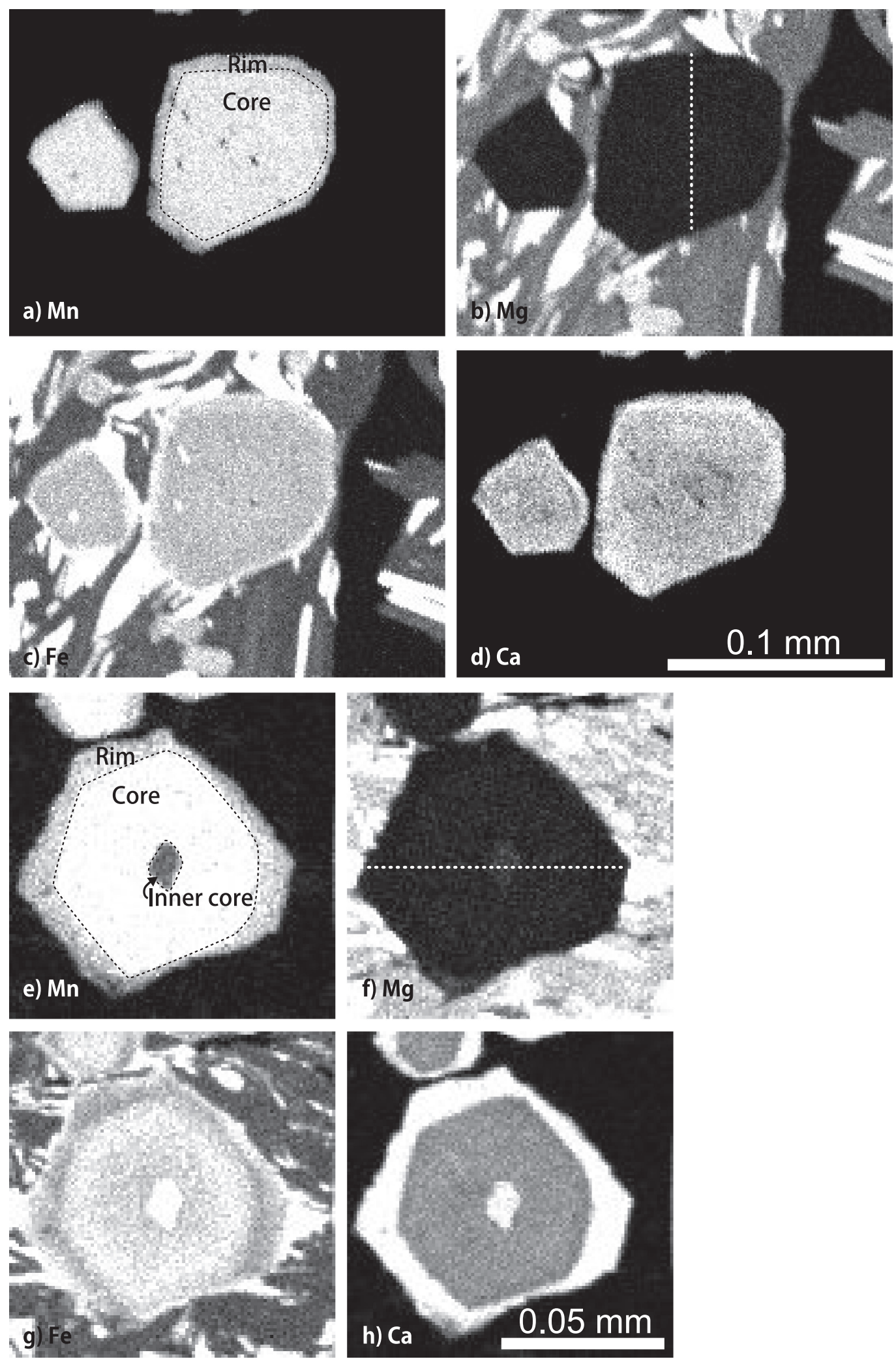

Figure 4. Mapped chemical profile of garnet grains in the studied outcrop. (a)-(d) mapping of a grain in sample HT2014a1 (grain number garnet 2), (e)-(h) mapping of a grain in 20160902TAP (grain number P1-1-5). Both grains have euhedral, relatively large homogeneous cores. $\mathrm{Mn}$ and Fe decreases in the rim compared to the core. (h) shows Ca increase in the rim. (e)-(h) show an irregular shaped inner core. Chemical line profiles along the dotted lines on (e) and (h) are shown in Figure 5. Color version is available online from https://doi.org/ $10.2465 /$ jmps.170712b. 

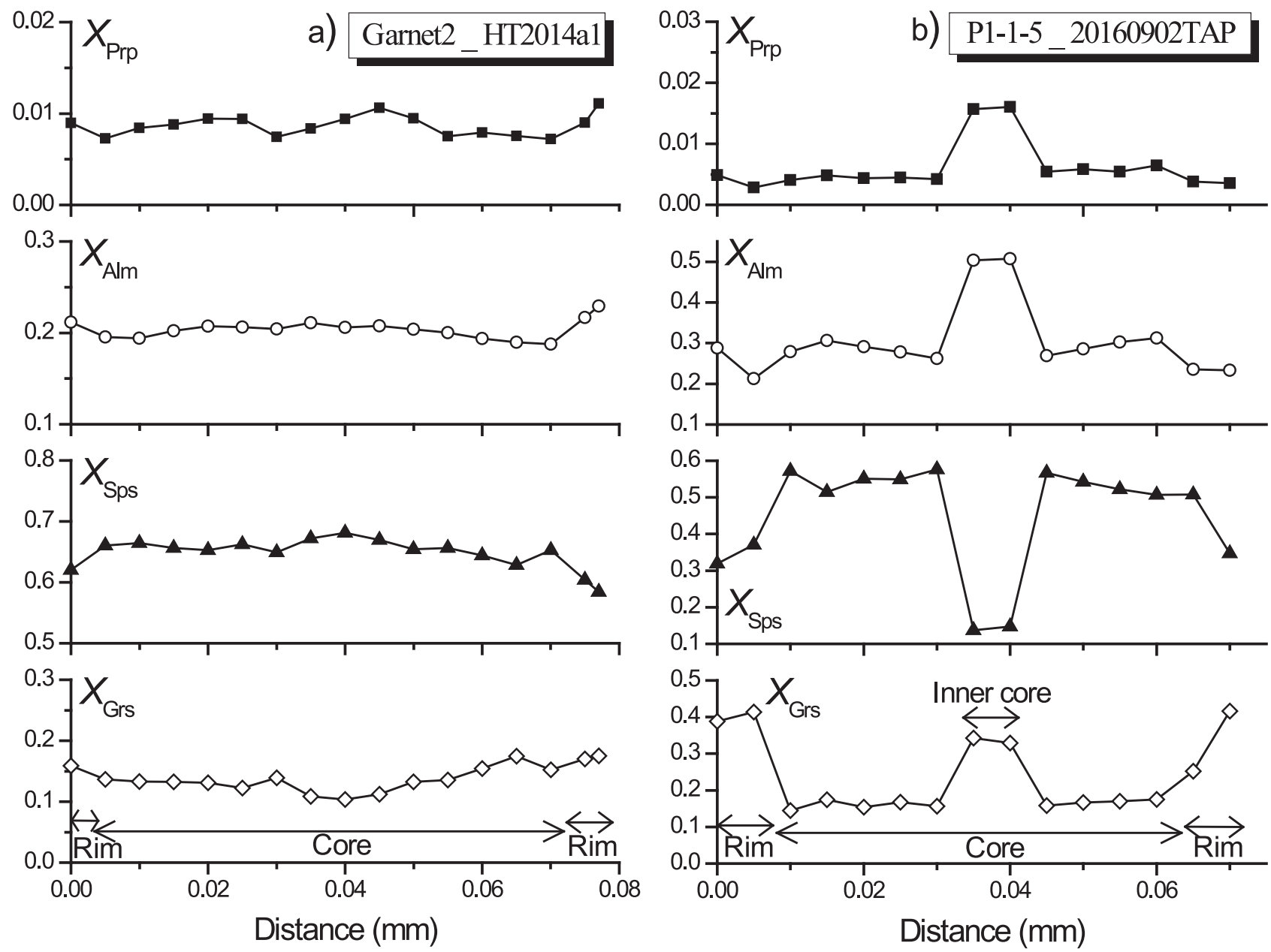

Figure 5. Chemical composition profile of garnet grains (traverse). (a) chemical composition profile of sample HT2014a1 (grain number garnet 2), (b) chemical composition profile of sample 20160902TAP (grain number P1-1-5).

Table 1. Representative chemical composition of garnet and chlorite analyzed by EPMA

\begin{tabular}{|c|c|c|c|c|c|c|c|}
\hline \multirow[b]{3}{*}{$\mathrm{wt} \%$} & \multicolumn{3}{|c|}{ Sample HT2014al } & \multicolumn{4}{|c|}{ Sample 20160902TAP } \\
\hline & \multicolumn{2}{|c|}{ Grt } & \multirow[b]{2}{*}{$\mathrm{Chl}$} & \multicolumn{3}{|c|}{ Grt } & \multirow[b]{2}{*}{ Chl } \\
\hline & Core & Rim & & $\begin{array}{l}\text { Inner } \\
\text { core }\end{array}$ & Core & Rim & \\
\hline $\mathrm{SiO}_{2}$ & 36.38 & 36.33 & 24.52 & 37.05 & 36.22 & 37.32 & 24.69 \\
\hline $\mathrm{TiO}_{2}$ & 0.20 & 0.16 & 0.05 & 0.14 & 0.14 & 0.16 & 0.02 \\
\hline $\mathrm{Al}_{2} \mathrm{O}_{3}$ & 19.74 & 20.00 & 20.81 & 20.51 & 20.27 & 21.03 & 20.26 \\
\hline $\mathrm{FeO}^{*}$ & 9.24 & 10.64 & 30.53 & 23.30 & 12.62 & 9.73 & 30.58 \\
\hline $\mathrm{MnO}$ & 29.64 & 25.44 & 1.37 & 6.25 & 24.44 & 16.82 & 0.75 \\
\hline $\mathrm{MgO}$ & 0.24 & 0.26 & 10.34 & 0.39 & 0.15 & 0.09 & 11.05 \\
\hline $\mathrm{CaO}$ & 4.58 & 6.97 & 0.00 & 12.39 & 5.85 & 14.78 & 0.02 \\
\hline Total & 100.02 & 99.80 & 87.62 & 100.03 & 99.69 & 99.93 & 87.37 \\
\hline
\end{tabular}

Abbreviations for minerals are: Grt, garnet; Chl, chlorite. See Figure 4 for the definition of the inner core, the core, and the rim of garnet.

${ }^{*}$ Total iron as $\mathrm{FeO}$. have experienced higher grade metamorphic condition compared to the garnet-free rocks, indicating post-metamorphic juxtaposition of rocks with different thermal history. The story seems possible since previous studies have claimed that tectonic contacts do exist in this area, based on the spatial variation of estimated temperatures using the degree of graphitization, even though the contacts are not observable in the field (Hashimoto et al., 1992; Tagiri et al., 2003). However, within the studied outcrop, the estimated temperatures by Inui et al. (2018) are neither significantly different between the garnet-bearing and garnet-free samples, nor between the rocks on both sides of the structural discontinuity (Fig. 3a). It is reasonable to assume that the rocks in the studied outcrop have similar thermal history. Chemical analyses showed that Mn-richer garnet rim was associated with Mn-richer chlorite. If the rocks exactly had the same bulk rock chemical composition from each other, and the variation of the chemical composition was entirely due to the exchange reaction after the peak metamorphism, the Mn-richer garnet should 


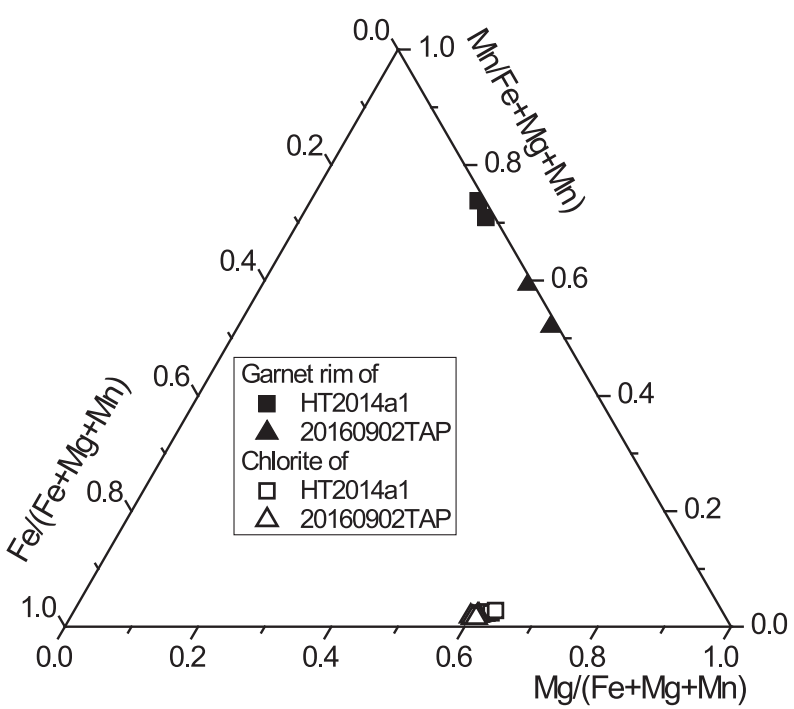

Figure 6. Chemical composition of garnet rim and adjacent chlorite in samples HT2014a1 and 20160902TAP. Sample HT2014a1 shows high Mn content in both garnet rim and chlorite, which is inexplicable by later exchange reaction between the two minerals. The large variance of the analytic result is mostly due to the steep zoning near the garnet-rim. The analytical resolution is nearly $0.01 \mathrm{~mm}$ whereas the garnet rim is zoned within 0.01 to $0.02 \mathrm{~mm}$. The analyses may not show the true rim value, but the variance shows the difference between samples.

be accompanied by Mn-poorer chlorite, since the total amount of Mn should not change. The trend in this study is consistent with the bulk chemical composition change between samples. The chlorite chemical composition is practically the bulk chemical composition in this mineral assemblage, as argued by Ghent et al. (1987). It is possible that bulk chemical composition controlled not only the chemical composition of garnet but also the nucleation of it. Pattison and Seitz (2012) observed in a hydrothermal reaction area that larger amount of $\mathrm{Mn}$ and $\mathrm{Fe}$ in the bulk chemical composition increases garnet stability. The observation is consistent with the thermodynamic calculation (Inui and Toriumi, 2004) that increase in $\mathrm{Mn}$ or Fe in the bulk (chlorite) chemical composition lowers the garnet-in temperature greatly. The paired trend of garnet and chlorite chemical composition is consistent with the bulk chemical control on the garnet formation, where $\mathrm{Mn}$ richer chlorite formed $\mathrm{Mn}$-richer garnet. Ca content has been known to show different chemical zoning profile in garnet compared to $\mathrm{Fe}-\mathrm{Mg}-\mathrm{Mn}$ system (Chernoff and Carlson, 1997; Spear and Daniel, 2001). It has been interpreted to be due to the different diffusion rate of the elements: sluggish diffusion of $\mathrm{Ca}$ cation sometimes results in disequilibrium crystal growth only in $\mathrm{Ca}$. In the study area, however, less than half of the samples contain calcite and it is not appropriate to discuss the influence of $\mathrm{Ca}$ on the same basis. Sample HT2014al (Figs. 4a-4d) contains calcite, whereas sample 20160902TAP (Figs. 4e-4h) does not contain calcite. It is more likely that the difference in $\mathrm{Ca}$ zoning in this studied outcrop is due to the $\mathrm{Ca}$-minerals that participated in $\mathrm{Ca}$-garnet formation. The issue needs more surveillance and will not be discussed further for now. Another possibility is that the rocks were partly influenced by some fluid flux during metamorphism. Fluid flow may have dramatically promoted material transport in limited parts of rocks and that could enhance nucleation of garnet (e.g., Skelton, 1997). In the samples of this study, however, the garnet grains were selectively located in the micaceous lamellae, where they could get their reaction materials very handy. This texture indicates that not enough amount of reaction materials was available in the siliceous lamellae to nucleate garnet. Magnitude of material transport during the garnet growth must have been small. Thus, influence of fluid flow is inconsistent with the texture observed in this study.

\section{Implication of the texture of garnet}

The chemical composition of the preserved inner core with irregular shape is $\mathrm{Mn}$-poor, Ca-rich, and discontinuous with the surrounding core part (Fig. 4e). The trend is different from that of the disequilibrium 'Mn-caldera' reported by Yoshida and Hirajima (2015), Mn content of which is largely continuous with the outer part. Furthermore, the size of their 'Mn-caldera' is far larger (several millimeters), and the shape is almost euhedral. It is more likely that the inner core found in this study is not a product of disequilibrium grain growth, but is a detrital garnet grain.

Chemical composition profile of garnet grains from the core to the rim indicates that the grains have experienced small temperature increase during growth. The high Mn content in the core indicate that the start of growth occurred in relatively low temperature (Inui and Toriumi, 2004). The size of the homogeneous Mn-rich core part was relatively large compared to the total size of the grains. Normal prograde chemical zoning was only developed near the outline of the grain which is small in volume. The proportion implies that the grains experienced little temperature increase after core formation. Small grain size is consistent with the indication that the growth did not continue for long. Furthermore, the texture that garnet grains only occur in the micaceous lamellae, most of them associated with chlorite, is also consistent with limited time for growth of garnet, since the texture suggests sluggish material transport during growth. The texture is consistent with that expected when garnet just nucleated and grew at locations where they had abundant materials (chlorite), as argued by Spear and Daniel (2001). 
The sharp euhedral chemical zoning profile indicates that the garnet grains are not influenced by later events. It is possible that they cooled relatively soon preserving the texture. The large size of the homogeneous core also indicates a certain level of thermal overstepping. If no overstepping of temperature is assumed, the size of the garnet core at the nucleation temperature must be infinitesimally small and will not grow larger unless the temperature increases. Homogeneous part does not occur in that case. The size, shape, texture, and the chemical profile of garnet grains are all consistent with the model that the garnet grains nucleated and started to grow just before the rock cooled and the texture was preserved. It is explained that the garnet grains started to grow during the last stage of the prograde metamorphism.

\section{ACKNOWLEDGMENTS}

The authors are grateful to Y. Kouketsu and K. Yoshida for their help and comments that were really constructive for me to shape up the data and the manuscript. The authors are also grateful to T. Hirajima for his encouragement to submit their data and M. Enami for his kind handling. The authors would like to thank S. Yamamoto and S. Aoki for their assistance on the analysis at the University of Tokyo, Y. Kouketsu and other members of the group for the analysis at Nagoya University, and M. Uno for his aerial photos which helped them a lot when mapping their data. The authors are always thankful to the members of the lab, especially those who supplied and organized their samples for use in this study, and those who helped measuring the topography.

\section{SUPPLEMENTARY MATERIAL}

Color version of Figure 4 is available online from https:// doi.org/10.2465/jmps.170712b.

\section{REFERENCES}

Aoya, M. (2001) $P-T-D$ Path of Eclogite from the Sambagawa Belt Deduced from Combination of Petrological and Microstructural Analyses. Journal of Petrology, 42, 1225-1248.

Banno, S. and Sakai, C. (1989) Geology and metamorphic evolution of the Sanbagawa belt. In Evolution of Metamorphic Belts (Daly, J.S., Cliff, R.A. and Yardley, B.W.D. Eds.). Geological Society, London, Special Publication, 43, 519-532.

Beyssac, O., Goffé, B., Chopin, C. and Rouzaud, J.N.R. (2002) Raman spectra of carbonaceous material in metasediments: a new geothermometer. Journal of Metamorphic Geology, $20,859-871$.

Chernoff, C.B. and Carlson, W.D. (1997) Disequilibrium for Ca during growth of pelitic garnet. Journal of Metamorphic Geology, 15, 421-438.
Enami, M. (1998) Pressure-temperature path of Sanbagawa prograde metamorphism deduced from grossular zoning of garnet. Journal of Metamorphic Geology, 16, 97-106.

Enami, M., Wallis, S.R. and Banno, Y. (1994) Paragenesis of sodic pyroxene-bearing quartz schists: implications for the P-T history of the Sanbagawa belt. Contributions to Mineralogy and Petrology, 116, 182-198.

Gaidies, F., Pattison, D.R.M. and de Capitani, C. (2011) Toward a quantitative model of metamorphic nucleation and growth. Contributions to Mineralogy and Petrology, 162, 975-993.

Ghent, E.D., Stout, M.Z., Black, P.M. and Brothers, R.N. (1987) Chloritoid-bearing rocks associated with blueschists and eclogites, northern New Caledonia. Journal of Metamorphic Geology, 5, 239-254.

Hashimoto, M., Tagiri, M., Kusakabe, K., Masuda, K. and Yano, T. (1992) Geologic structure formed by tectonic stacking of sliced layers in the Sanbagawa metamorphic terrain, Kodama-Nagatoro area, Kanto Mountains. Journal of the Geological Society of Japan, 98, 953-965. (in Japanese with English abstract)

Higashino, T. (1990) The higher grade metamorphic zonation of the Sambagawa metamorphic belt in central Shikoku, Japan. Journal of Metamorphic Geology, 8, 413-423.

Inui, M. and Toriumi, M. (2004) A theoretical study on the formation of growth zoning in garnet consuming chlorite. Journal of Petrology, 45, 1369-1392.

Inui, M., Izumi, R. and Watanabe, T. (2018) Estimated peak metamorphic temperature of the Sanbagawa schists from Nagatoro area, Kanto Mountains, using Raman microspectrometry on carbonaceous materials. Transactions of the Kokushikan University Faculty of Science and Engineering, 11, 55-60.

Kato, T. (2005) New accurate Bence-Albee $\alpha$-factors for oxides and silicates calculated from the PAP correction procedure. Geostandards and Geoanalytical Research, 29, 83-94.

Pattison, D.R.M. and Seitz, J.D. (2012) Stabilization of garnet in metamorphosed altered turbidites near the St. Eugene leadzinc deposit, southeastern British Columbia: Equilibrium and kinetic controls. Lithos, 134-135, 221-235.

Sakai, C. (1980) Biotite zone in the Sambagawa metamorphic terrain east of Onishi-machi, Kanto Mountains. Journal of the Geological Society of Japan, 86, 517-524 (in Japanese with English abstract).

Sakai, C., Banno, S., Toriumi, M. and Higashino, T. (1985) Growth history of garnet in pelitic schists of th Sanbagawa metamorphic terrain in central Shikoku. Lithos, 18, 81-95.

Skelton, A.D.L. (1997) The effect of metamorphic fluid flow on the nucleation and growth of garnets from Troms, North Norway. Journal of Metamorphic Geology, 15, 85-92.

Spear, F.S. and Selverstone, J. (1983) Quantitative P-T paths from zoned minerals: theory and tectonic applications. Contributions to Mineralogy and Petroloty, 83, 348-357.

Spear, F. and Daniel, C. (2001) Diffusion control of garnet growth, Harpswell Neck, Maine, USA. Journal of Metamorphic Geology, 19, 179-195.

Spear, F., Thomas, J. and Hallett, B. (2014) Overstepping the garnet isograd: a comparison of QuiG barometry and thermodynamic modeling. Contributions to Mineralogy and Petrology, $168,1059-1073$.

Tagiri, M., Matsumoto, T. and Tanimoto, K. (2003) Reevaluation of the precision of the degree of graphitization, and the boundaries between shuffled-cards in the Sanbagawa metamorphic belt, Kanto Mountains, Japan. Japanese Magazine of Minera- 
logical and Petrological Sciences, 32, 175-184 (in Japanese with English abstract).

Tsutsumi, Y., Miyashita, A., Terada, K. and Hidaka, H. (2009) SHRIMP U-Pb dating of detrital zircons from the Sanbagawa Belt, Kanto Mountains, Japan: need to revise the framework of the belt. Journal of Mineralogical and Petrological Sciences, 104, 12-24.

Whitney, D.L. and Evans, B.W. (2010) Abbreviations for names of rock-forming minerals. American Mineralogist, 95, 185-187.
Yoshida, K. and Hirajima, T. (2015) 3D chemical mapping of 'Mncaldera shaped zoning' garnet found from the Sanbagawa metamorphic belt of the Besshi district, SW Japan. Journal of Mineralogical and Petrological Sciences, 110, 197-213.

Manuscript received July 12, 2017

Manuscript accepted April 23, 2018

Manuscript handled by Masaki Enami 